\title{
Comparative response of Callosobruchus maculatus (Fab.) (Coleoptera: Chysomelidae) to Momordica charantia and Acalypha wilkesiana powders in stored cowpea (Vigna unguiculata (L.) Walp.)
}

\section{Respuesta comparativa de Callosobruchus maculatus (Fab.) (Coleoptera: Chysomelidae) a polvos de Momordica charantia y Acalypha wilkesiana en caupí almacenado (Vigna unguiculata (L.) Walp.)}
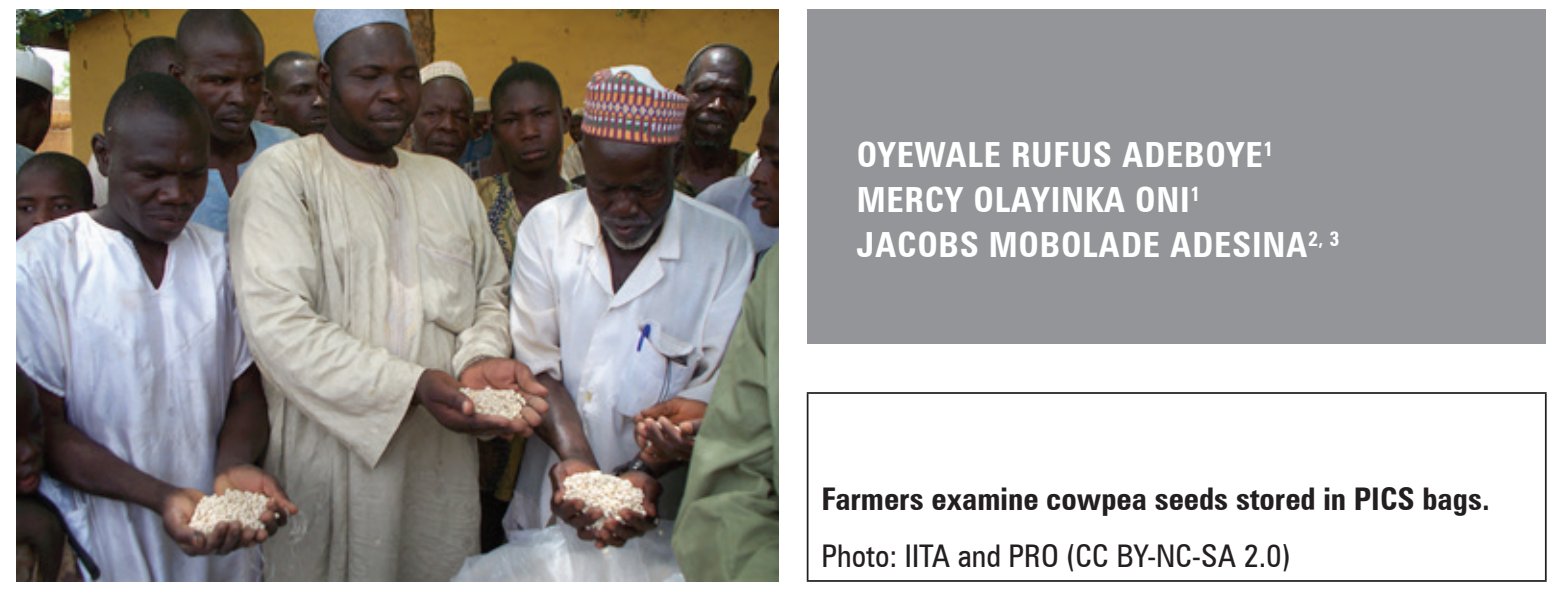

\section{ABSTRACT}

The post-harvest preservation of cowpea in developing countries has been a major challenge because of Callosobruchus maculatus infestations. This study compared the response of C. maculatus (F.) to Momordica charantia and Acalypha wilkesiana powders in stored cowpea seeds under laboratory conditions. Five pairs of freshly emerged C. maculatus adults were introduced into a Petri-dish containing $20 \mathrm{~g}$ of cowpea admixed with 0.2 , $0.4,0.6$ and $0.8 \mathrm{~g}$ of each plant powder. This procedure was replicated three times in a completely randomized design. The adult mortality was recorded at 24 hours intervals for 5 days, and oviposition was recorded after 48 hours. In addition, newly emerged insects were recorded 30-35 days after infestation, and weight loss was also determined. The treatments had a significant increase in $C$. maculatus adult mortality as the exposure period and dosage increased; the highest values (90 and 100\% for A. wilkesiana and $M$. charantia, respectively)

Federal University of Technology Akure, Department of Crop, Soil and Pest Management, Akure (Nigeria). ORCID Adeboye, O.R.: 0000-0002-4679-821X; ORCID Oni, M.O.: 0000-0002-3053-3567

2 Rufus Giwa Polytechnic, Department of Crop, Soil and Pest Management Technology, Owo (Nigeria). ORCID Adesina, J.M.: 0000-0003-1174-9095

3 Corresponding author. moboladesina@rugipo.edu.ng 
were observed at 120 hours of exposure with the $0.8 \mathrm{~g}$ dosage level. At $0.8 \mathrm{~g}$, the A. wilkesiana (66.3) and M. charantia (63.0) treated seeds recorded a significantly lower number of eggs laid. Similar trend was observed for adult emergence and weight loss percentage. This study revealed that both plants had a significant insecticidal effect but $M$. charantia was more effective than A. wilkesiana, without significant differences in the assessed parameters. This indicated that these plant powders potentially protect stored cowpea seeds from C. maculatus infestations and damage. Therefore, these plants should be included in Integrated Pest Management Strategies for cowpea storage by small scale farmers.

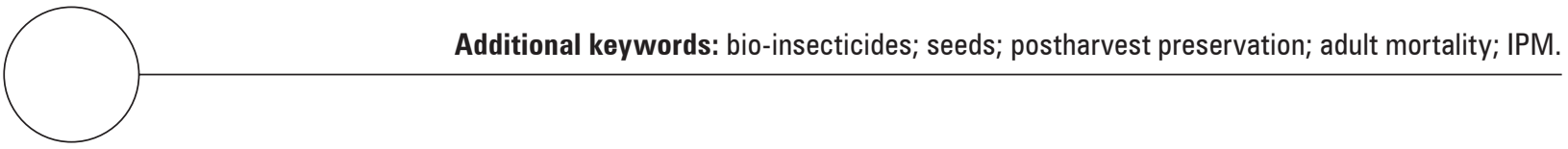

\section{RESUMEN}

La preservación poscosecha del caupí en los países en desarrollo ha sido un desafío importante debido a la infestación de Callosobruchus maculatus. El estudio compara la respuesta de C. maculatus (F.) a los polvos de Momordica charantia y Acalypha wilkesiana en semillas de caupí almacenadas en atmósfera de laboratorio. Se introdujeron cinco pares de adultos de C. maculatus recién emergidos en una placa de Petri que contenía 20 g de caupí mezclados con 0,2; 0,4; 0,6 y $0,8 \mathrm{~g}$ de cada polvo de planta, replicados tres veces y dispuestos en un diseño completamente al azar. La mortalidad adulta se registró en un intervalo de 24 horas durante 5 días, la oviposición se registró después de 48 h. Mientras que los insectos recién emergidos se registraron 30-35 días después de la infestación y también se determinó la pérdida de peso. Los tratamientos mostraron un aumento significativo en la mortalidad de adultos de C. maculatus a medida que aumenta el tiempo de exposición y la dosis, con valores más altos (90 y 100\% para A. willesiana y $M$. charantia, respectivamente) a las 120 horas de exposición y dosis de $0,8 \mathrm{~g}$. Con $0,8 \mathrm{~g}$, las semillas tratadas de $A$. wilkesiana $(66,3)$ y $M$. charantia $(63,0)$ registraron un número significativamente menor de huevos puestos. Se observó igualmente una tendencia similar para la emergencia de adultos y el porcentaje de pérdida de peso. El estudio reveló que ambas plantas tenían efectos insecticidas significativos y mostró claramente que $M$. charantia fue más eficaz que $A$. wilkesiana, pero no mostró diferencias significativas más altas en todos los parámetros evaluados. Esto indicó que estos polvos de plantas tienen posibilidades de proteger las semillas de caupí almacenadas de la infestación y el daño de C. maculatus. Por lo tanto, estas plantas deben incluirse en las Estrategias de Manejo Integrado de Plagas para el almacenamiento de caupí por parte de pequeños agricultores.

Palabras clave adicionales: bioinsecticidas; semillas; preservación poscosecha; mortalidad de adultos; IPM.

Received for publication: 27-07-2019 Accepted for publication: 11-06-2020

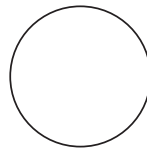

The cowpea, Vigna unguiculata (L.) Walp., is a multifunctional crop that provides food for humans and livestock. It is a valuable and dependable revenuegenerating commodity widely grown by farmers in all agro-ecological zones in Nigeria. The cowpea is a major staple food crop in sub-Saharan Africa and a major source of inexpensive dietary proteins that complement expensive animal sources of protein in many developing nations.

In most developing countries, small scale cowpea cultivation plays a substantial role in rural economies.
Small scale farmers face severe post-harvest problems from bruchid infestations, particularly in grain storage. Research has shown that the bruchid developmental stages (Callosobruchus maculatus), under field and laboratory conditions, include: incubation period, duration of larvae stage evolution, pupae duration and longevity of new adults. The entire life cycle takes an optimum of $27 \mathrm{~d}$ at $30^{\circ} \mathrm{C}$ and $80 \%$ relative humidity (RH) (Kouninki et al., 2009).

Farmers who want to protect their produce from bruchid infestations use synthetic pesticides if they 
can afford them. These chemicals are frequently misused because the majority of small-scale farmers in many African countries are illiterate. The chemicals contaminate stored food, leaving behind harmful residues, especially when application dosages are not properly followed (Parugrug and Aurea, 2008). Synthetic pesticides are not only expensive but may also have harmful effects on the health of consumers. Moreover, some pests have developed some resistance to some synthetic pesticides, so alternative natural solutions to the bruchid problem in cowpea are needed.

The objective of this study was to compare the response of Callosobruchus maculatus to $M$. charantia and $A$. wilkesiana powders in stored cowpea.

\section{MATERIALS AND METHODOLOGY}

\section{Location of the experiment}

This study was carried out in the Department of Crop, Soil and Pest Management Laboratory of the Federal University of Technology, Akure (Ondo state, South-west Nigeria).

\section{Insect culture (Callosobruchus maculatus)}

The Callosobruchus maculatus adults used for the experiment were obtained from infested cowpea seeds from the Oja-Oba market, Owo, Ondo State. The cowpea seeds were put in a kilner jar covered with muslin, which prevented the insects from escaping and allowed for ventilation (Adesina et al., 2016). The jar was kept at room temperature $\left(28^{\circ} \mathrm{C}\right.$ and $75 \%$ $\mathrm{RH})$ to allow the insects to breed and multiply; the emerged insects were used for this experiment.

\section{Collection of cowpea seeds for bioassay}

The drum variety cowpea seeds used in the bioassay were obtained from the same market. The seeds were properly hand-picked and sieved, ensuring that only whole, uninfected seeds were used. These seeds were kept in a deep freezer for a week to kill any immature stage insects (if any), followed by air drying in the laboratory for $24 \mathrm{~h}$ to prevent mustiness (Adesina and Mobolade-Adesina, 2020) and storage in a cool dry place (Iloba and Ekrakene, 2006).

\section{Collection and preparation of plant materials}

Fresh $M$. charantia and A. wilkesiana leaves were obtained from Rufus Giwa Polytechnic, Owo, Ondo state and identified at the Department of Forestry and Wood Technology at the institution. The plant leaves washed with clean water to remove dirt and air dried at room temperature for $15 \mathrm{~d}$. Thereafter, the dried leaves were grounded into a powder using a hammer mill and sieved before storage in a tightly covered container.

\section{Application of plant materials}

Twenty grams of clean un-infested and disinfected cowpea seeds were weighed using a TS 400D digital balance (precision standard), which were placed in Petri-dishes with a $9 \mathrm{~cm}$ diameter. Thereafter, 0.2 , $0.4,0.6$ and $0.8 \mathrm{~g}$ of each pulverized plant's leaves were thoroughly mixed with the seeds inside each Petri-dish. Another Petri-dish containing $20 \mathrm{~g}$ of untreated cowpea seed was also prepared to serve as a control. Five pairs (10) of freshly emerged C. maculatus adults were introduced into each Petri-dish. Each treatment level was replicated three times in a completely randomized design on the laboratory workbenches.

The number of adult weevils that died were observed and recorded at $24 \mathrm{~h}$ intervals for $120 \mathrm{~h}(5 \mathrm{~d})$. The insects were jabbed using a blunt dissecting probe (Obeng-Oforie et al., 1997), and the insects that did not respond to three probes were considered dead. Thereafter, all insects were removed, and the experiment proceeded until adults (first filial generation) started to emerge. Oviposition was recorded at 48 $h$, along with the number of eggs laid on the seeds (usually whitish in color). The number of adults that emerged were counted and recorded after a period of 30-35 d; the newly emerged insects were removed after they were counted. The seed weight loss was determined after the experiment.

\section{Statistical analysis}

The data collected from the replicates were analyzed using analysis of variance. Mean separation was achieved using Tukey's Honest Significance Test. Prior to analysis, the data in percentage were arc sine transformed, while the data in count were square root transformed. 


\section{RESULTS}

Comparative effect of $M$. charantia and A. wilkesiana powders on the adult mortality of $C$. maculatus

Table 1 shows the adult mortality of $C$. maculatus in the cowpea seeds treated with the plant powders $(M$. charantia and A. wilkesiana). At the lowest dosage of $0.2 \mathrm{~g}$ with $24 \mathrm{~h}$ of exposure, both treatments had the lowest mortality (3.3\%); no mortality was recorded for the control. The treatments increased in the adult mortality of $C$. maculatus as the exposure period and dosage increased, with the highest values (90 and $100 \%$ for $A$. wilkesiana and $M$. charantia, respectively) observed with $120 \mathrm{~h}$ of exposure at the $0.8 \mathrm{~g}$ dosage level.

The $M$. charantia and A. wilkesiana powders were potent against $C$. maculatus because they recorded a higher percentage of beetle mortality (Tab. 1).

\section{Comparative effect of $M$. charantia and}

A. wilkesiana powders on oviposition suppression in C. maculatus

Table 2 shows the oviposition suppression activity of $M$. charantia and A. wilkesiana powders in stored cowpea seeds. The untreated seeds (control) had the highest oviposition (175.0). The treatments had significant effects on the oviposition of the insects (C. maculatus), as compared with the control. At the 0.2 g dosage, the Acalypha wilkesiana treated seeds had 107.7 eggs laid by the insects. M. charantia had 105.7 eggs laid by the insects. At the $0.4 \mathrm{~g}$ dosage level, $A$. wilkesiana and $M$. charantia recorded 97.0 and 88.3 eggs, respectively. At the $0.6 \mathrm{~g}$ dosage level, Acalypha. Wilkesiana recorded 84.7 eggs laid on the stored cowpea seeds, and $M$. charantia recorded 70.3 eggs. At the $0.8 \mathrm{~g}$ dosage level, the $A$. wilkesiana treated seeds had 66.3 eggs laid by the insects, while $M$. charantia had 63.0 eggs.

\section{Table 2. Comparative effect of $M$. charantia and $A$. wilkesi- ana powders on C. maculatus oviposition.}

\begin{tabular}{|c|c|c|}
\cline { 2 - 3 } \multicolumn{1}{c|}{} & \multicolumn{2}{c|}{ Plants powders } \\
\hline Dosage level & A. wilkesiana & M. charantia \\
\hline $0.0 \mathrm{~g}$ & $162.3 \pm 0.10 \mathrm{a}$ & $175.0 \pm 2.40 \mathrm{a}$ \\
\hline $0.2 \mathrm{~g}$ & $107.7 \pm 1.20 \mathrm{~b}$ & $105.7 \pm 0.13 \mathrm{bc}$ \\
\hline $0.4 \mathrm{~g}$ & $97.0 \pm 0.09 \mathrm{de}$ & $88.3 \pm 2.65 \mathrm{~cd}$ \\
\hline $0.6 \mathrm{~g}$ & $84.7 \pm 1.86 \mathrm{f}$ & $70.3 \pm 0.20 \mathrm{e}$ \\
\hline $0.8 \mathrm{~g}$ & $66.3 \pm 0.00 \mathrm{~g}$ & $63.0 \pm 0.00 \mathrm{~g}$ \\
\hline
\end{tabular}

Each value is the mean \pm standard error of the three replicates. Values with same letter(s) do not differ significantly at $P>0.05$ using Tukey's honest significance test.

\section{Comparative effect of $M$. charantia and \\ A. wilkesiana powders on adult emergence in C. maculatus}

Table 3 shows the activity of the plants powders ( $M$. charantia and A. wilkesiana) on adult emergence in $C$. maculatus on stored cowpea seeds.

Table 1. Comparative effect of $\boldsymbol{M}$. charantia and $\boldsymbol{A}$. wilkesiana powders on $\boldsymbol{C}$. maculatus adult mortality.

\begin{tabular}{|l|c|c|c|c|c|}
\cline { 2 - 7 } \multicolumn{1}{c|}{} & \multicolumn{5}{c|}{ Period of exposure (h) } \\
\hline Treatment & $24 \mathrm{~h}$ & $48 \mathrm{~h}$ & $72 \mathrm{~h}$ & $96 \mathrm{~h}$ & $120 \mathrm{~h}$ \\
\hline $0.0 \mathrm{~g}$ (Control) & $0.0 \pm 0.00 \mathrm{a}$ & $0.0 \pm 0.00 \mathrm{a}$ & $0.0 \pm 0.00 \mathrm{a}$ & $0.0 \pm 0.00 \mathrm{a}$ & $6.7 \pm 3.33 \mathrm{a}$ \\
\hline $0.2 \mathrm{~g}$ (A. wilkesiana) & $3.3 \pm 3.33 \mathrm{ab}$ & $13.3 \pm 3.33 \mathrm{~b}$ & $23.3 \pm 3.33 \mathrm{~b}$ & $36.7 \pm 3.33 \mathrm{~b}$ & $53.3 \pm 3.33 \mathrm{~b}$ \\
\hline $0.2 \mathrm{~g}$ (M. charantia) & $3.3 \pm 3.33 \mathrm{ab}$ & $23.3 \pm 3.33 \mathrm{bc}$ & $36.7 \pm 3.33 \mathrm{bc}$ & $53.3 \pm 3.33 \mathrm{bc}$ & $63.3 \pm 3.33 \mathrm{~b}$ \\
\hline $0.4 \mathrm{~g}$ (A. wilkesiana) & $10.0 \pm 0.00 \mathrm{bc}$ & $30.0 \pm 0.00 \mathrm{cde}$ & $43.3 \pm 3.33 \mathrm{~cd}$ & $56.7 \pm 3.33 \mathrm{c}$ & $66.7 \pm 3.33 \mathrm{bc}$ \\
\hline $0.4 \mathrm{~g}$ (M. charantia) & $13.3 \pm 3.33 \mathrm{c}$ & $33.3 \pm 3.33 \mathrm{cde}$ & $46.7 \pm 3.33 \mathrm{cde}$ & $66.7 \pm 3.33 \mathrm{c}$ & $6.7 \pm 3.33 \mathrm{bcd}$ \\
\hline $0.6 \mathrm{~g}$ (A. wilkesiana) & $13.3 \pm 3.33 \mathrm{c}$ & $33.3 \pm 3.33 \mathrm{cde}$ & $56.7 \pm 3.33 \mathrm{cde}$ & $70.0 \pm 5.77 \mathrm{~cd}$ & $0.0 \pm 0.00 \mathrm{bcd}$ \\
\hline $0.6 \mathrm{~g}$ (M. charantia) & $16.7 \pm 3.33 \mathrm{c}$ & $40.0 \pm 0.00 \mathrm{de}$ & $66.7 \pm 3.33 \mathrm{fg}$ & $83.3 \pm 3.33 \mathrm{~d}$ & $90.0 \pm 5.77 \mathrm{~cd}$ \\
\hline $0.8 \mathrm{~g}$ (A. wilkesiana) & $20.0 \pm 0.00 \mathrm{c}$ & $40.0 \pm 0.00 \mathrm{de}$ & $60.0 \pm 0.00 \mathrm{ef}$ & $83.3 \pm 3.33 \mathrm{~d}$ & $90.0 \pm 0.00 \mathrm{~cd}$ \\
\hline $0.8 \mathrm{~g}$ (M. charantia) & $20.0 \pm 0.00 \mathrm{c}$ & $46.7 \pm 3.33 \mathrm{e}$ & $76.7 \pm 3.33 \mathrm{~g}$ & $100.0 \pm 0.00 \mathrm{e}$ & $100.0 \pm 0.00 \mathrm{~d}$ \\
\hline
\end{tabular}

Each value is the mean \pm standard error of the three replicates. Values in the same column with same letter(s) do not differ significantly at $P>0.05$ using Tukey's honest significance test. 
The result showed that there was a significant effect from the plant powders on the adult emergence of weevils in the stored seeds, as compared with the control. The control recorded the highest number of C. maculatus adult emergence (114.3). The $M$. charantia powder at the $0.8 \mathrm{~g}$ dosage level resulted in the lowest number of adult emergences (40.0). At the 0.2 , 0.4 and $0.6 \mathrm{~g}$ dosage levels, there was no significant difference between the two plant powders. At the 0.8 $\mathrm{g}$ dosage level, there was a significant difference between the $M$. charantia (40.0) and A. wilkesiana powders (48.7).

Table 3. Comparative effect of $M$. charantia and A. wilkesiana powders on adult emergence in $C$. maculatus.

\begin{tabular}{|c|c|c|}
\cline { 2 - 3 } \multicolumn{1}{c|}{} & \multicolumn{2}{c|}{ Plants powders } \\
\hline Dosage level & A. wilkesiana & M. charantia \\
\hline $0.0 \mathrm{~g}$ & $114.3 \pm 0.18 \mathrm{a}$ & $113.7 \pm 3.53 \mathrm{a}$ \\
\hline $0.2 \mathrm{~g}$ & $79.0 \pm 0.33 \mathrm{~b}$ & $67.0 \pm 1.15 \mathrm{~b}$ \\
\hline $0.4 \mathrm{~g}$ & $66.3 \pm 1.20 \mathrm{c}$ & $60.7 \pm 0.33 \mathrm{c}$ \\
\hline $0.6 \mathrm{~g}$ & $57.0 \pm 0.33 \mathrm{de}$ & $51.0 \pm 0.33 \mathrm{de}$ \\
\hline $0.8 \mathrm{~g}$ & $48.7 \pm 0.00 \mathrm{~d}$ & $40.0 \pm 0.00 \mathrm{e}$ \\
\hline
\end{tabular}

Each value is the mean \pm standard error of the three replicates. Values with the same letter(s) do not differ significantly at $P>0.05$ using Tukey's honest significance test.

\section{Comparative effect of Momordica charantia and Acalypha wilkesiana powders on C. maculatus weight loss activity in stored cowpea seeds}

Table 4 shows the effect of the $M$. charantia and A. wilkesiana powders on weight loss in the stored cowpea seeds as caused by cowpea weevils. The results showed that the seeds without powder (control) had

\section{Table 4. Comparative effect of $M$. charantia and A. wilkesi- ana powders on $C$. maculatus weight loss activity in stored cowpea seeds.}

\begin{tabular}{|c|c|c|}
\cline { 2 - 3 } \multicolumn{1}{c|}{} & \multicolumn{2}{c|}{ Plant powders } \\
\hline Dosage level & A. wilkesiana (\%) & M. charantia (\%) \\
\hline $0.0 \mathrm{~g}$ & $17.2 \pm 0.05 \mathrm{~d}$ & $17.2 \pm 0.00 \mathrm{~d}$ \\
\hline $0.2 \mathrm{~g}$ & $12.3 \pm 0.3 \mathrm{~d}$ & $12.3 \pm 0.02 \mathrm{~d}$ \\
\hline $0.4 \mathrm{~g}$ & $10.0 \pm 0.05 \mathrm{bc}$ & $10.8 \pm 0.05 \mathrm{bc}$ \\
\hline $0.6 \mathrm{~g}$ & $8.0 \pm 0.32 \mathrm{~b}$ & $8.0 \pm 0.08 \mathrm{~b}$ \\
\hline $0.8 \mathrm{~g}$ & $6.7 \pm 0.13 \mathrm{a}$ & $6.7 \pm 0.12 \mathrm{a}$ \\
\hline
\end{tabular}

Each value is the mean \pm standard error of the three replicates. Values with same letter(s) do not differ significantly at $P>0.05$ using Tukey's honest significance test. the highest weight loss percentage (17.2\%), which resulted from the insect infestation, followed by the seeds treated with the $0.2 \mathrm{~g}$ dosage level of $M$. charantia and A. wilkesiana (12.3\%), the $0.4 \mathrm{~g}$ dosage level in seeds treated with $M$. charantia $(10.8 \%)$ and A. wilkesiana $(10.0 \%)$, the $0.6 \mathrm{~g}$ dosage level in seeds treated with the two plant powders (8.0\%), and the $0.8 \mathrm{~g}$ dosage level in seeds treated with the two plant powders, which had the lowest seed weight loss percentage $(6.7 \%)$.

\section{DISCUSSION}

The main tactic for controlling insect pests during storage has been centered on the use of synthetic insecticides and fumigants but they have several drawbacks. Alternative botanicals are a panacea for the problems caused by the use of synthetics insecticides and fumigants. The high insecticidal effect of $M$. charantia and A. wilkesiana recorded in this study may have been due to insecticidal properties. In addition, these powders may block the spiracle of the beetles, resulting in suffocation and death (lleke and Olotuah, 2012; Oni, 2014; Oni et al., 2018a). The efficacy and effectiveness of these plant powders $(M$. charantia and A. wilkesiana) may also result from phytochemicals, such as glycosides, alkaloid, sapon, and tannis, among others, found in the plants. Since most of these compounds have been reported as causing insect mortality, the high C. maculatus mortality seen with the plant powders of $M$. charantia and $A$. wilkesiana could be associated with the presence of one or more of these compounds (Obembe and Ogungbite, 2017).

The study revealed that maximum oviposition suppression was observed with $M$. charantia and $A$. wilkesiana, while the minimum oviposition suppression was found in the control (untreated seeds). Increasing the dosage levels suppressed the ovipositions, as shown in table 2, which agrees with Olaifa and Erhun (1998), Oni et al. (2018b), and Adesina et al. (2012), who found that a higher concentration of a powder made from Piper guineense and $M$. charantia significantly reduced the oviposition rate and that these plant powders might possess repellent and/or oviposition suppression properties. Oviposition suppression may be due to changes induced in the physiology and behavior in C. maculatus adults, as reflected in their eggs laying capacity.

The significant effects of the plant powders in inhibiting adult emergence could be attributed to a biocidal 
property that suppresses C. maculatus oviposition in stored cowpea seeds. A significant reduction in adult emergence was observed between the treatments. The efficacy of the plant powders ( $M$. charantia and A. wilkesiana) was much stronger against F1 than against egg laying (oviposition), as found by Jayakumar et al. (2003), who reported that plant products have an obvious effect on the postembryonic survival of insects, resulting in a reduction in adult emergence with all concentrations of plant powders. Raja et al. (2001) stated that botanicals inhibit C. maculatus adult emergence in cowpea. He further stated that, when eggs are laid on treated seeds, the toxic substance in the plant products may enter through chorion, suppressing their embryonic development. In the present study, adult emergence was greatly reduced in the treated seeds, as compared with the control seeds (untreated seeds).

The significant reduction in weight loss in the treated cowpea grains may have resulted from the ability of the plant powders (M. charantia and A. wilkesiana) to suppress oviposition and adult emergence in the cowpea weevils in the stored cowpea seeds. These results support the findings of Adesina et al. (2012), who claimed that $M$. charantia leaf powder has great potential for use as an admixture in stored cowpea seeds for small scale farmers, reducing insect pest infestation damage, increasing mortality, and suppressing oviposition, adult emergent and weight loss.

\section{CONCLUSION}

The results of this study showed that the effectiveness of the plant powders ( $M$. charantia and $A$. wilkesiana) was dependent on the dosage and exposure period, with significant effects on all accessed parameters that evidenced the entomocidal potential of protecting stored cowpea grains from C. maculatus infestations. Because of their relative availability, easy preparation, easy application, cheap cost, nontoxic properties, greater ability and higher influence on C. maculatus infestations in stored cowpea seeds, it is recommended that $M$. charantia and A. wilkesiana powders be used in Integrated Pest Management by small scale farmers or shops for protecting short term cowpea storage from $C$. maculatus infestations. Further studies are recommended to determine the mode of action responsible for the insecticidal properties and the phytochemical profile of the plant materials.
Conflict of interests: this manuscript was prepared and reviewed with the participation of the authors, who declare that there exists no conflict of interest that puts the validity of the presented results at risk.

\section{BIBLIOGRAPHIC REFERENCES}

Adesina, J.M., L.A. Afolabi, and T.I. Ofuya. 2012. Evaluation of insecticidal properties of Momordica charantia in reducing oviposition and seed damage by Callosobruchus maculatus (Fab.). J. Agric. Technol. 8(2), 493-499.

Adesina, J.M. and T.E. Mobolade-Adesina. 2020. Callosobruchus maculatus (Fab.) (Coleoptera: Chrysomelidae) infestation and tolerance on stored cowpea seeds protected with Anchomanes difformis (Blume) Engl. extracts. J. Hortic. Post-Harvest Res. 3(2), 367-378.

Adesina, J.M., T.I. Ofuya, and Y. Rajashekar. 2016. Efficacy of some plant extracts against cotton strainers, Dysdercus superstitious (Herrich Schaffer) (Hemiptera: Pyrrhocoridae). J. Entomol. Zool. Stud. 4(4), 170-174.

Ileke, K.D. and O.F. Olotuah. 2012. Bioactivity of Anacardium occidentale (L.) and Allium sativum (L.) powders and oils extract against cowpea bruchid, Callosobruchus maculatus (Fab.). [Coleoptera: Chrysomelidae]. Int. J. Biol. 4(1), 96-103. Doi: 10.5539/ijb.v4n1p96

Iloba, B.N. and T. Ekrakene. 2006. Daily mortality responses of Callosobruchus maculatus and Sitophiltus zeamais to change in the concentration of Azadirachta indica, Ocilmum gratissium and Hyptis svaveolens. J. Entomol. 3(4), 271-276. Doi: 10.3923/je.2006.271.276

Jayakumar, M., N. Raja, and S. Ignacimuthu. 2003. Efficacy of crude extracts of Hyptis suaveolens and Melochia corchorifolia on pulse beetle Callosobruchus maculatus. pp. 218-221. In: Ignacimuthu, S. and J. Eyaraj (eds.). Biological control of insect pests. Phoenix Publishing House, New Delhi.

Kouninki, H., S. Ngamo, T. Hance, and M.B. Ngassoum. 2009. Potential use of essential oils from local Cameroonian plants for the control of red flour weevil Tribolium castaneum. Afr. J. Food Agric. Nutr. Dev. 7, 1-15.

Obembe, O.M. and O.C. Ogungbite. 2017 Comparative insecticidal activities of some botanical powders and pirimiphos-methyl against Callosobruchus maculatus Fab. (Coleoptera: Bruchidae) infesting cowpea seeds. MOJ Biol. Med. 2(4), 305-309. Doi: 10.15406/ mojbm.2017.02.00063

Obeng-Oforie, D., C.H. Reichnuth, J. Bekele, and A. Hassan-Ali. 1997. Biological activity of 1, 8 cimeole a major component of essential oil of Ocimum kenyense (Ayobamgia) against stored product beetle. J. Appl. Entomol. 121, 237-243. Doi: 10.1111/j.14390418.1997.tb01399.x

Olaifa, J.I. and W. Erhun. 1998. Laboratory evaluation of Piper guineense for the protection of cowpea against 
Callosobruchus maculatus. Int. J. Trop. Insect Sci. 9(1), 55-59. Doi: 10.1017/S1742758400010031

Oni, M.O. 2014. Entomotoxic efficacy of cayenne pepper, sweet pepper and long cayenne pepper oil extracts against Sitophilus zeamais infesting maize grain. Mol. Entomol. 5(5), 37. Doi: 10.5376/me.2014.05.0005

Oni, M.O., O.C. Ogungbite, and T.I. Ofuya. 2018a. Biotoxic efficacy of different fractions of Acalypha godseffiana oil extracts against Callosobruchus maculatus infesting stored cowpea. Med. Plant Res. 8(2), 8-13. Doi: 10.5376/mpr.2018.08.0002

Oni, M.O., B. Oyawoye, R.A. Adebayo, T.I. Ofuya, and O.C. Ogungbite. 2018b. Entomocidal efficacy of crude oil and fractions of Mormodica charantia (L) oil extract against cowpea bruchid Callosobruchus maculatus $(\mathrm{Fab})$ infesting stored cowpea seeds. Appl. Trop. Agric. 23(1), 120-125.

Parugrug, M.L. and C. Aurea. 2008. Insecticidal action of five plants against maize weevil, Sitophilus Zeamais Motsch. (Coleptera: Curculionidae). KMITL Sci. Tech. J. 8(1), 24-38.

Raja, N., A. Babu, S. Dorn, and S. Ignacimuthu. 2001. Potential of plants $f$ or protecting stored pulses from Callosobruchus maculatus (Coleoptera: Bruchidae) infestation. Biol. Agric. Hortic. 19, 19-27. Doi: 10.1080/01448765.2001.9754906 